\title{
Dokumen Perancangan Perangkat Lunak Exam Management System (EMS) Institut Teknologi Telkom Purwokerto
}

\author{
Viryal Nabila, Puan Elina Abwa Aba*, Endah Rizka, Citra Wiguna \\ Program Studi Sistem Informasi, Fakultas Informatika, \\ Institut Teknologi Telkom Purwokerto, \\ Jawa Tengah, INDONESIA \\ 20103162@ittelkom-pwt.ac.id,20103165@ittelkom-pwt.ac.id*,20103166@ittelkom-pwt.ac.id, citra@ittelkom-pwt.ac.id
}

\begin{abstract}
Abstrak - Teknologi informasi dalam bidang pendidikan berkembang pesat secara eksponensial, hal tersebut dibuktikan oleh adanya berbagai macam e-learning. Learning Management System adalah suatu web belajar yang digunakan oleh mahasiswa maupun dosen untuk mengupload materi, menginput data nilai, merekap absensi mahasiswa, melihat jadwal mengajar. Pada masa pandemi, perguruan tinggi dituntut untuk melakukan seluruh kegiatan belajar mengajar secara daring. Penelitian ini bertujuan untuk menyusun dokumen EMS sebagai acuan dalam sistem ujian online yang terintegrasi tindakan untuk mengintegrasikan seluruh ujian online. Sistem manajemen ujian atau Exam Management System (EMS) adalah sebuah sistem untuk melaksanakan ujian yang digunakan oleh mahasiswa internal dan dapat juga digunakan oleh pihak akademik untuk menunjang pembelajaran secara online. EMS ini ditujukan untuk mengurangi kecurangan dalam pengerjaan soal ujian. EMS dapat membantu dosen dalam mengoreksi hasil ujian mahasiswa serta dapat mengetahui kecurangan saat ujian dikarenakan EMS diperlengkapi dengan fitur plagiarisme. Fitur ini hanya terdapat pada EMS dosen, yang berarti mahasiswa tidak dapat mengakses fitur plagiarism. Sistem ujian ini dibangun berbasiskan website dengan mengimplementasikan algoritma Fisher-Yates Shuffle dan algoritma Lavenshtein Distance. Kedua algoritma tersebut berfungsi untuk mengacak soal membandingkan jawaban pada saat pengoreksian, dan cek plagiarism. EMS dikembangkan dengan menganalisis dan merancang dokumen Deskripsi Perancangan Perangkat Lunak (DPPL). DPPL dijadikan dasar tahapan pengembangan dan implementasi sistem.
\end{abstract}

Kata Kunci: Plagiarisme; DPPL; EMS; LMS; Ujian.

\section{Pendahuluan}

LMS (Learning Management System) adalah suatu web belajar yang digunakan oleh mahasiswa maupun dosen untuk mengupload materi, menginput data nilai, merekap absensi mahasiswa, melihat jadwal mengajar, akses materi, soal, KRS dan lain-lain. Kondisi saat ini LMS IT Telkom telah digunakan pada hampir seluruh mata kuliah namun dalam penggunaanya masih terdapat kendala baik dari segi dosen maupun mahasiswa.

Kendala LMS dari sisi dosen antara lain; (1) Tidak adanya fitur untuk mengetahui tindak kecurangan mahasiswa sehingga sulit untuk dosen mengukur tingkat pengetahuan mahasiswanya; (2) Keterbatasan ukuran file dokumen terkait pengunggahan materi, soal dan jawaban dengan maksimal ukuran file 64 MB; dan (3) Kurangnya variasi jawaban dan pilihan koreksi sehingga dosen masih harus melakukan koreksi manual untuk jawaban dari soal essay.

Dari sisi mahasiswa terdapat kendala antara lain; (1) Dalam pengadaan ujian, LMS tidak mempunyai ruang khusus untuk ujian semuanya tergabung dalam satu ruang mata kuliah dengan materi dan kuis sehingga terjadi keterbatasan kecepatan akses mahasiswa yang mengikuti ujian dan mahasiswa yang sedang mengikuti kelas perkuliahan; (2) Keterbatasan ukuran dan jumlah file dokumen terkait pengunggahan jawaban dengan maksimal ukuran file $64 \mathrm{MB}$ dan maksimal satu dokumen saja yang dapat diunggah; (3) Sulit untuk melakukan perubahan akses kelas dalam setiap mata kuliah yang diambil [1].

Berdasarkan kendala yang telah dikemukakan diatas penelitian ini mengusulkan sebuah rancangan deskripsi perangkat lunak berupa Exam Management System (EMS) sebagai solusi. EMS adalah sebuah sistem yang mampu membantu mahasiswa dalam mengerjakan ujian meskipun terkendala jarak yang jauh.

EMS juga akan menghadirkan fitur yang dapat berguna untuk berlangsungnya ujian online mahasiswa antara lain seperti jadwal ujian, penginputan soal dan nilai yang akan muncul setelah dosen mengoreksi. Soal yang didapatkan masahasiswa nantinya akan diacak sehingga sebisa mungkin mengurai bentuk tindakan plagiarisme antar mahasiswa sekelasnya. Plagiarisme adalah sebuah kesamaan atau penjiplakan hasil karya orang lain yang melanggar hak cipta.

Faktor-faktor penyebab timbulnya perilaku plagiarisme tersebut ada tiga bentuk yaitu; (1) Pengambilan tulisan orang lain dan diakui sebagai karya sendiri; (2) Pengambilan ide atau pikiran untuk dimodifikasi ke bahasa sendiri; (2) Pengambilan teks secara keseluruhan tanpa mengubah tulisan maupun menambah dengan analisis maupun komentar apapun [2]. 
Sistem ini dapat membantu mahasiswa dalam mengerjakan ujian dengan nyaman tanpa adanya tindak plagiarisme. Sehingga dapat menghindari hasil nilai yang berat sebelah akibat plagiarisme dan hasil yang didapatkan akan mutlak, didukung dengan belum diadakannya pembelajaran offline atau tatap muka.

EMS dirancang untuk memudahkan penggunanya dengan fitur-fitur yang mudah dipahami oleh pengguna sehingga dapat memberikan kenyamanan dan ketertiban dalam pelaksanaan ujian berbasis online. EMS ini mampu memberikan kemudahan bagi mahasiswa maupun dosen dalam melaksanakan kegiatan belajar mengajar dengan menerapkan metode jarak jauh.

Pada kondisi pandemi seperti ini mengharuskan orang-orang melakukan berbagai kegiatan secara online atau daring. Contohnya saja saat ujian yang harus berlangsung secara online, dengan adanya ujian online ini sering terjadinya sever down dikarenakan banyaknya server yang masuk secara bersamaan, selain itu juga saat ujian online ini dapat menyebabkan kecurangan dalam mengerjakkan ujian [3]. Dengan adanya EMS ini dapat membantu dosen dalam mengoreksi hasil ujian dari mahasiswa apakah terdapat kecurangan atau tidak dengan adanya fitur plagiarisme yang dapat mengecek hasil jawaban antar mahasiswa apakah terdapat jawaban yang sama persis [4].

Berdasarkan permasalahan yang telah dikemukakan maka penelitian ini menyusun suatu dokumen perancangan EMS yang berfungsi untuk memudahkan dosen dalam manajemen hal terkait ujian.

Sistem merupakan kumpulan berbagai komponen (fisik ataupun nonfisik) yang saling berkaitan satu sama lain untuk mencapai tujuan tertentu [5]. Manajemen merupakan ilmu untuk merancang, mengorganisasi, memotivasi, dan mengendalikan proses bisnis untuk mencapai tujuan [6]. Sistem Manajemen Ujian atau Exam Management System (EMS) adalah sebuah system untuk melaksanakan ujian yang digunakan oleh mahasiswa dan dapat juga digunakan oleh pihak-pihak yang bersangkutan di bidang akademik dengan fasilitas mengupload materi, menginput data nilai, merekap absensi mahasiswa, melihat jadwal mengajar dan melihat plagiarisme [7].

DPPL atau Deskripsi Perancangan Perangkat Lunak merupakan dokumen lanjutan dari dokumen Spesifikasi Kebutuhan Perangkat Lunak (SKPL) [8]. Pembuatan dokumen DPPL telah diatur dalam standar IEEE 1016 2009. DPPL terdiri dari dokumentasi perancangan yang dijadikan acuan untuk melakukan tahapan implementasi sistem [9].

DPPL merupakan dokumen rancangan yang berfungsi untuk memberikan gambaran secara spesifik mengenai rancangan perangkat lunak yang dibangun serta memastikan bahwa semua fungsi dan prosedur yang dibuat telah memenuhi spesifikasi kebutuhan sesuai dokumen SKPL yang telah dibuat.

\section{Metode Penelitian}

Tahap penelitian ini terdiri dari tiga langkah utama, yaitu observasi masalah, analisis kebutuhan fungsional, dan perancangan kebutuhan DPPL berupa; (1) Desain Arsitektural; (2) Deskripsi Komponen; (3) Diagram Use Case; (4) Diagram Sekuensial; (5) Diagram Kelas; dan (6) Rancangan Antar Muka.

Langkah pertama; Observasi masalah berupa proses berlangsungnya ujian banyak terjadi kecurangan, LMS tidak memiliki fitur koreksi jawaban otomatis, dan cek plagiarism sehingga sering terjadi kesamaan jawaban.

Langkah kedua; Analisis kebutuhan fungsional sistem dimulai dari langkah-langkah berikut ini; (1) Unggah dokumen dalam bentuk soft file dan sesuaikan berdasarkan kategori sekaligus dilakukan penyimpanan ke dalam sistem; (2) EMS mengolah data yang masuk dengan megimplementasikan algoritma Fisher-Yates Shuffle dan Lavenshtein Distance. Kedua algoritma tersebut berfungsi untuk mengacak soal dan membandingkan jawaban pada saat pengoreksian dengan cukup menyatukan jawaban record dan sistem akan melakukan banding jawaban antar dokumen; (3) Setelah pengolahan data berhasil dilakukan, sistem akan melanjutkannya dengan menampilkan hasil dari keluaran algoritma yang telah diterapkan yaitu list soal acak untuk menu ujian serta list data plagiarism yang akan ditampilkan pada menu check plagiarism.

Langkah ketiga; Perancangan kebutuhan DPPL berupa pembuatan atau perancangan arsitektur sistem, komponen fitur sistem, use case, sekuensial, kelas, dan antar muka.

\section{Hasil dan Pembahasan}

Penelitian ini dilakukan dengan melakukan perancangan dokumen DPPL dengan hasil sebagai berikut:

\section{A. Desain Arsitektural}

Desain arsitektur EMS ditunjukkan pada Gambar 1, pada gambar tersebut sistem ujian ini dibangun berbasiskan web. Halaman pertama sistem adalah halaman login user. Setelah pengguna melakukan login maka, pengguna akan masuk ke halaman menu dengan tampilan menu akan terlihat sesuai id pendaftaran aktor, aktor akan memilih menu record exam untuk admin, check plagiarism untuk dosen, dan start exam untuk mahasiswa. Masing-masing aktor akan diarahkan pada menu sesuai perannya yaitu klik jumlah kelas yang akan direcord untuk admin, pilih mata kuliah untuk dosen, dan masukkan kode akses ujian untuk mahasiswa. Record akan berjalan dengan ditandai lampu hijau untuk on air atau merah untuk off air, setelah record selesai maka file akan secara otomatis tersimpan. Check plagiarism akan memunculkan detail plagiarism mahasiswa apabila dosen telah melakukan klik menu mata kuliah dan mengisi kelas serta kategori ujian. Fitur mulai ujian pada mahasiswa akan dimulai apabila mahasiswa telah input kode akses ujian. 


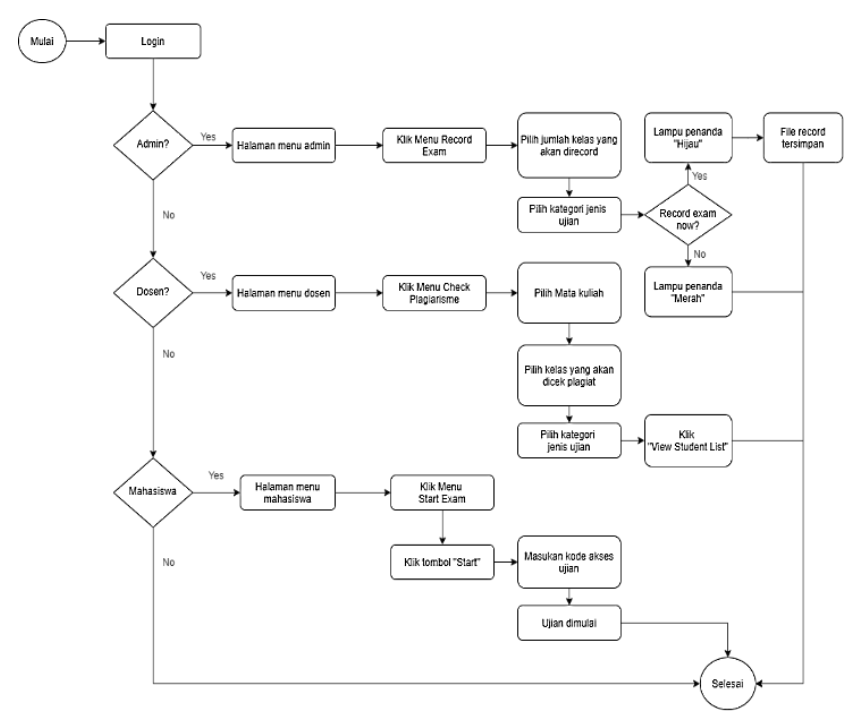

Gambar 1. Deskripsi Arsitektural Exam Management Sistem

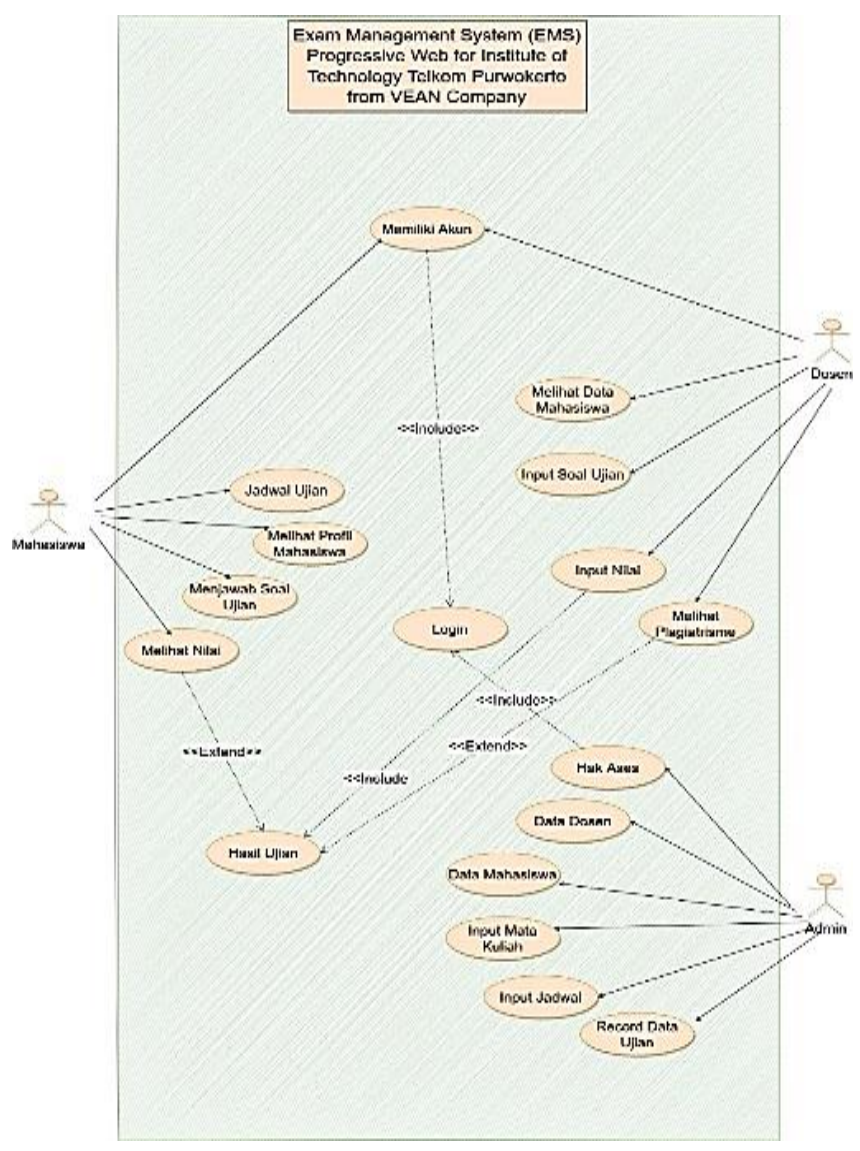

Gambar 2. Diagram Use Case

Tabel 1. Deskripsi Komponen

\begin{tabular}{cll}
\hline No. & \multicolumn{1}{c}{ Nama Komponen } & \multicolumn{1}{c}{ Keterangan } \\
\hline 1 & Login & $\begin{array}{l}\text { Halaman yang berfungsi untuk memasuki sistem } \\
\text { Menu admin untuk melakukan perekaman data } \\
\text { ujian mahasiswa secara live }\end{array}$ \\
2 & Menu Record Exam & $\begin{array}{l}\text { Menu dosen untuk melakukan pengecekan data } \\
\text { mahasiswa yang melakukan plagiarism dengan } \\
\text { ketentuan presentasi kesamaan }\end{array}$ \\
3 & Menu Check Plagiarisme & $\begin{array}{l}\text { Menu mahasiswa untuk melakukan ujian dengan } \\
\text { kode akses sebagai syarat dapat memulai ujian }\end{array}$ \\
& Menu Start Exam &
\end{tabular}




\section{B. Deskripsi Komponen}

Tabel 1 adalah deskripsi komponen fitur pada Exam Management Sistem.

\section{Diagram Use Case}

Hasil perancangan diagram use case dapat ditunjukan pada Gambar 2, use case yang dibangun atau dirancang terdiri dari tiga aktor utama yaitu mahasiswa, dosen dan admin. Aktor admin yaitu dapat hak akses, data dosen, data mahasiswa, input mata kuliah, input jadwal dan record data ujian. Aktor mahasiswa yaitu dapat melihat jadwal ujian, melihat profil mahasiswa, menjawab soal ujian, melihat nilai. Aktor dosen yaitu melihat data mahasiswa, input soal ujian, input nilai dan melihat hasil plagiarisme.

\section{Diagram Sekuensial}

Hasil perancangan diagram use case dapat ditunjukan pada Gambar 3, gambar ini terdiri dari tiga aktor yaitu dosen, mahasiswa dan admin. Sekuensial dosen dalam gambar atas menunjukkan dosen dapat melakukan cek plagiarisme. Sekuensial mahasiswa dapat melakukan ujian, sedangkan sekuensial admin dapat melakukan proses record jawaban.

\section{E. Diagram Kelas}

Hasil perancangan diagram kelas dapat ditunjukan pada Gambar 4, diagram kelas ini menjelaskan tentang relasi antar kelas berdasarkan diagram sekuensial yang telah dibuat sebelumnya. Diagram kelas ini diantaranya diagram kelas dosen, diagram kelas mahasiswa, dan diagram kelas admin.

\section{F. Rancangan Antar Muka}

Hasil perancangan diagram use case dapat ditunjukan pada Gambar 5, gambar dibawah menunjukkan desain rancangan antar muka system yang dibangun. Desain rancangan antar muka Exam Management System terdiri dari halaman login, check plagiarisme untuk halaman menu dosen, record ujian untuk halaman menu admin, dan mulai ujian untuk halaman menu mahasiswa.

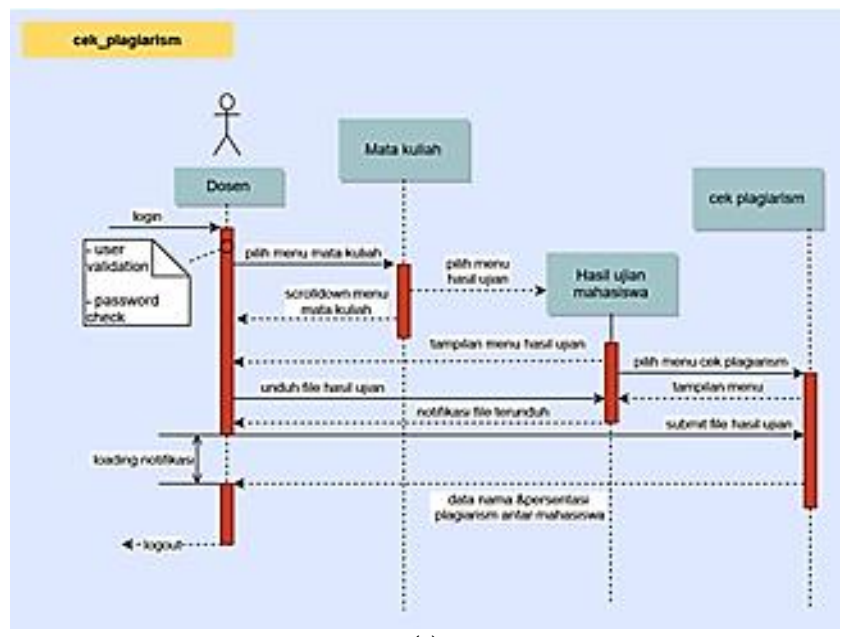

(a)

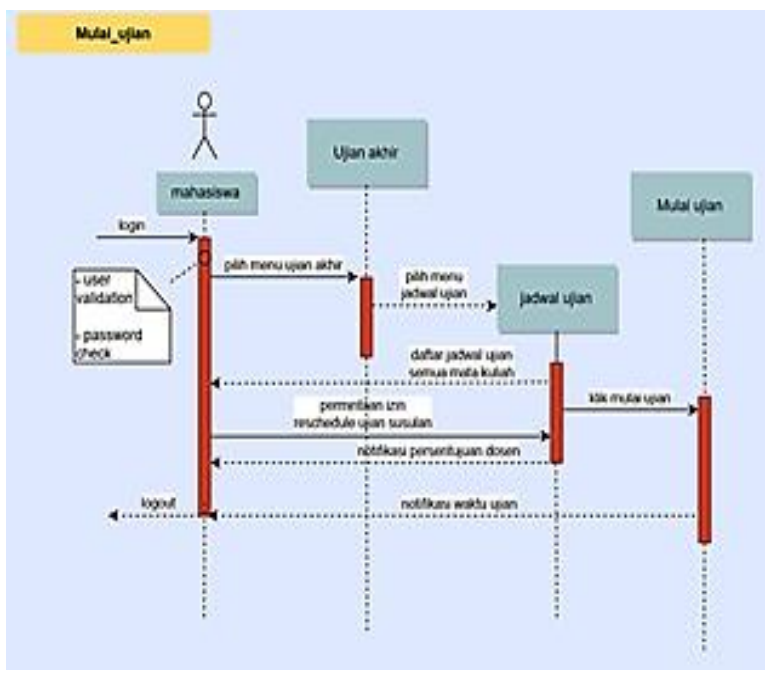

(b)

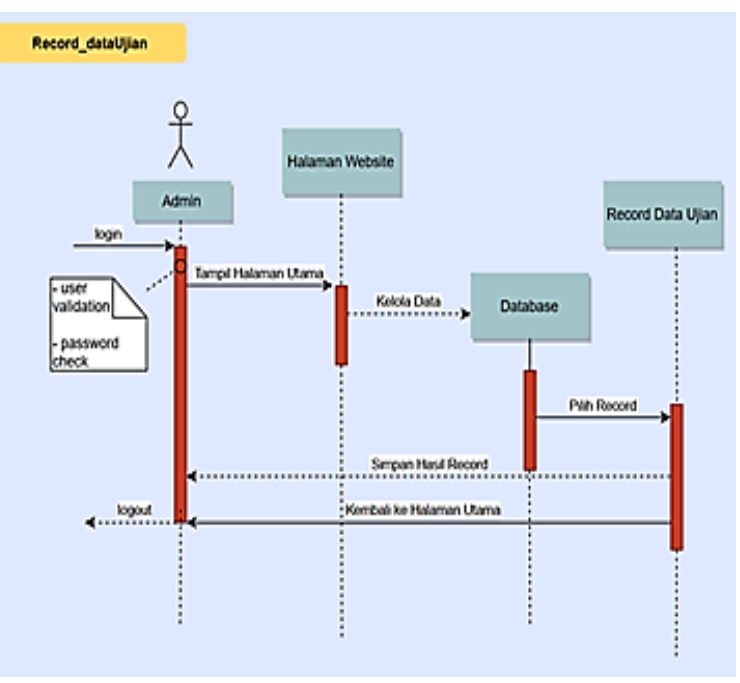

(c)

Gambar 3. Diagram Sequensial (a), (b), (c) 


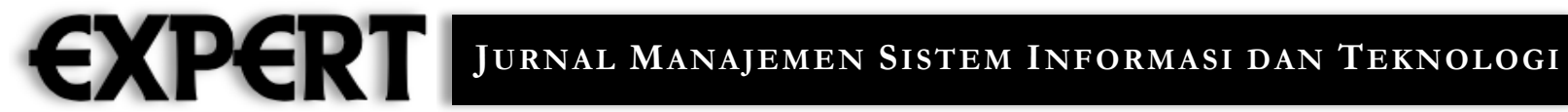

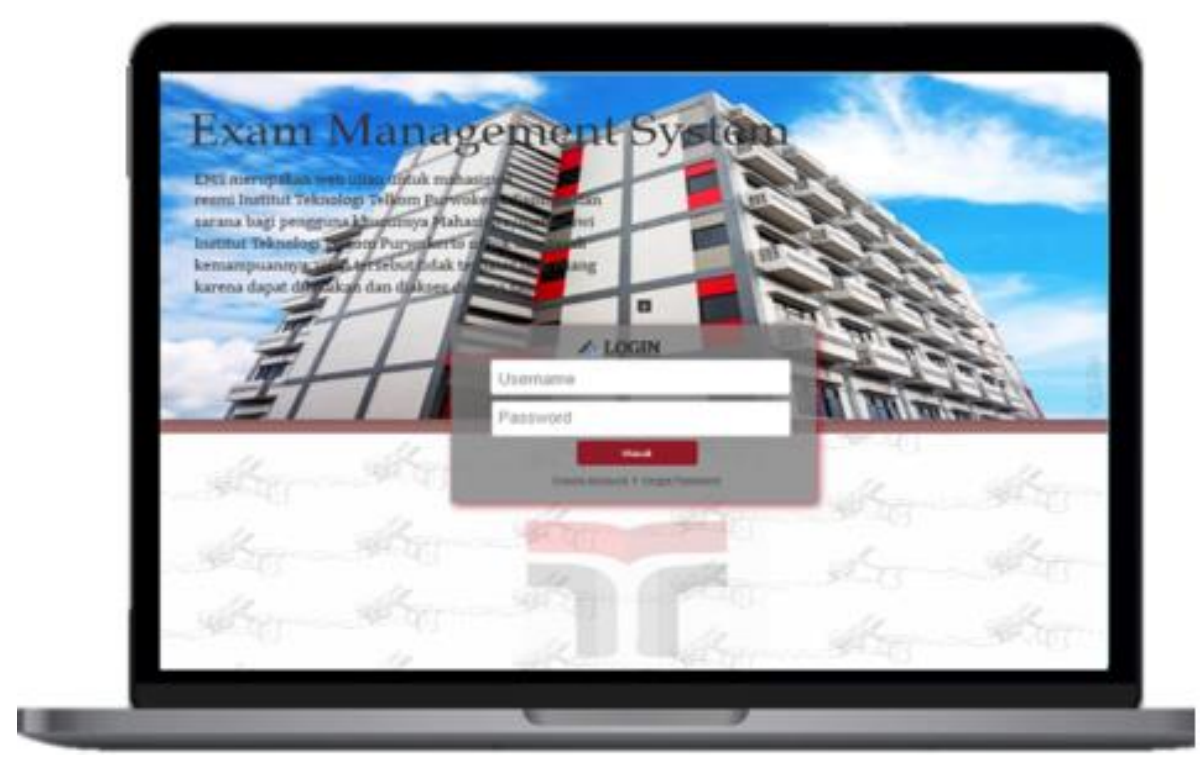

(a)

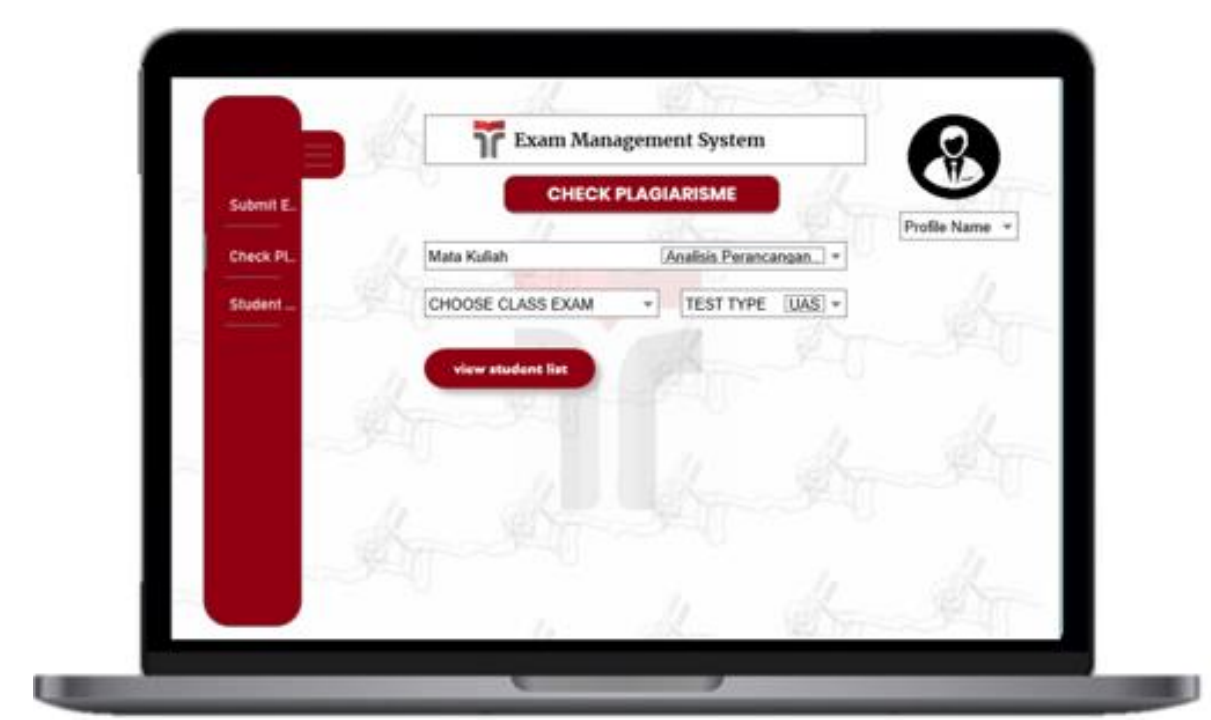

(b)

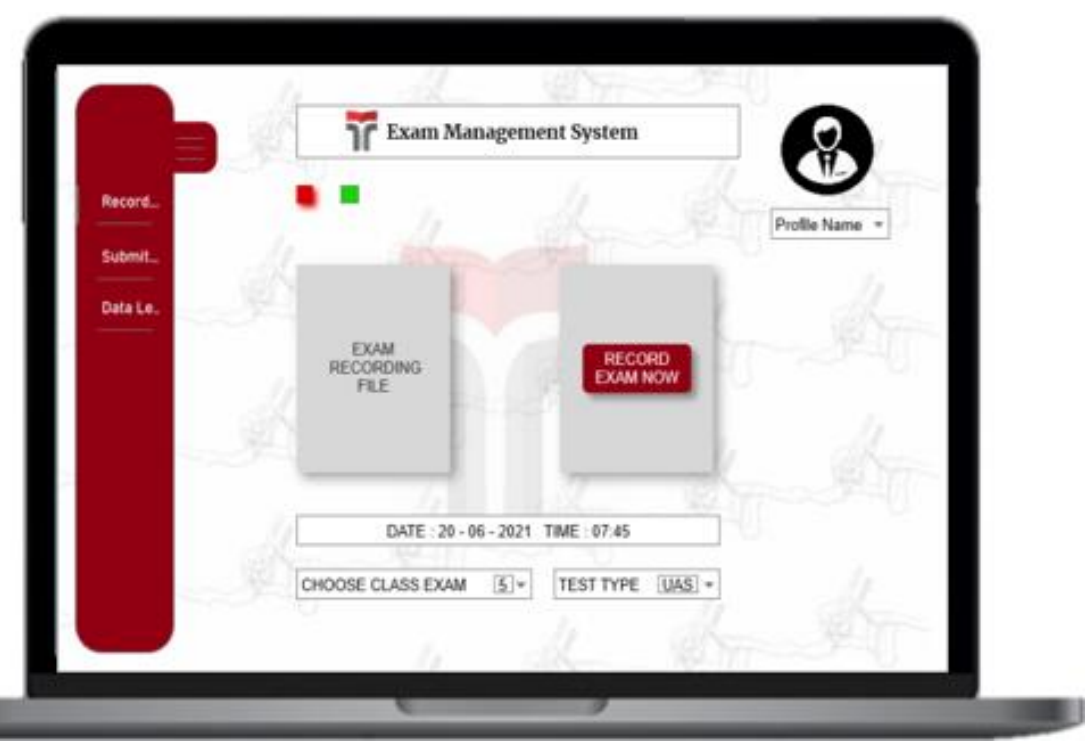

(c) 


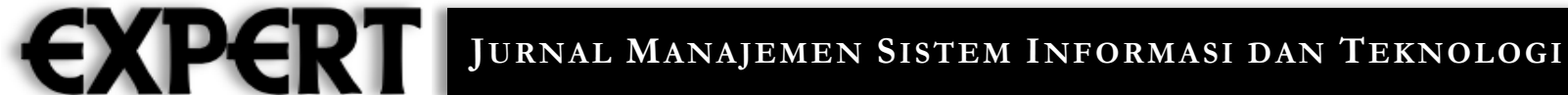

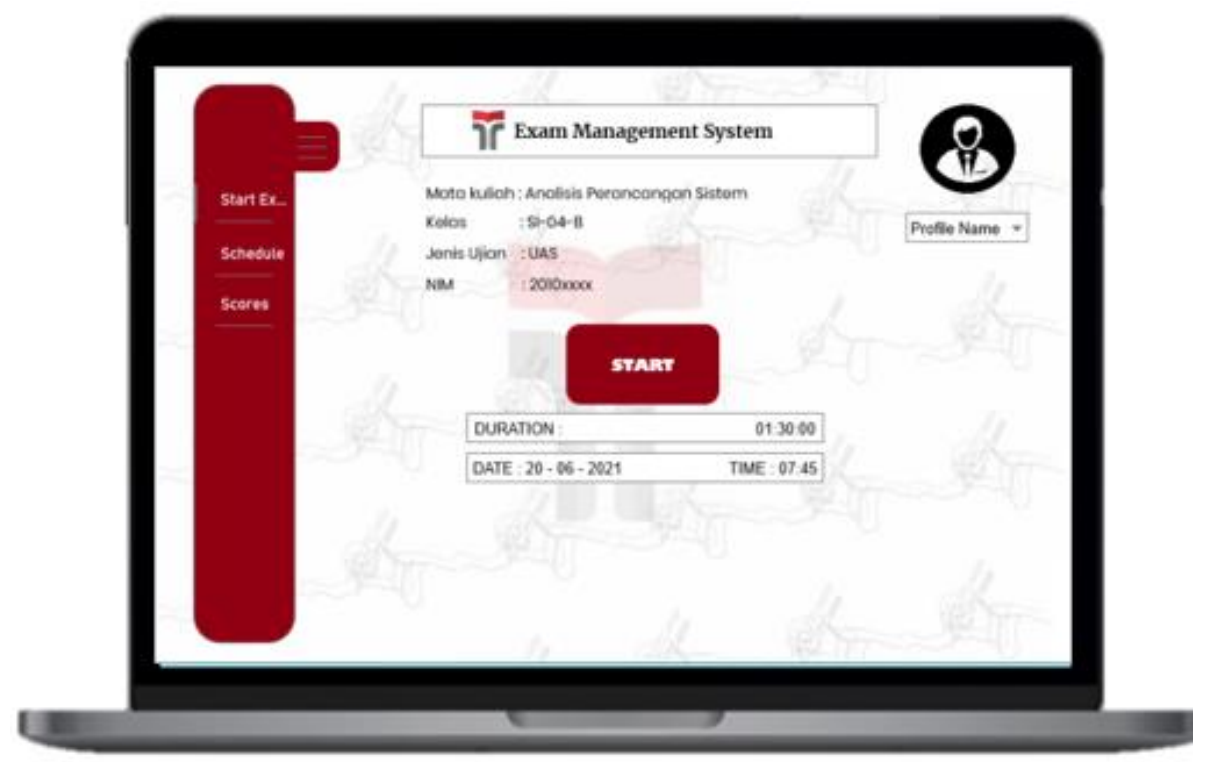

(d)

Gambar 5. Desain Antar Muka EMS (a), (b), (c), (d)

\section{Kesimpulan}

Kesimpulan dari penelitian yang telah dilakukan adalah; Analisis dan perancangan berhasil dibuat sesuai dengan tahapan penelitian dan dapat dijadikan dasar untuk pengembangan dan implementasi sistem; dan DPPL terdapat pembahasan tentang deskripsi arsitektur, deskripsi komponen, diagram use case, diagram sekuensial, diagram kelas dan rancangan antar muka.

\section{Daftar Pustaka}

[1] Sistem Informasi ITTelkom Purwokerto, "Learning Management System ITTP." Purwokerto, 2020, [Online]. Available: https://lms.ittelkom-pwt.ac.id/.

[2] I. Akib and M. Ibrahim, "Fenomena Plagiarisme Mahasiswa," Equilib. J. Pendidik., vol. 4, no. 1, pp. 20-29, 2017, doi: 10.26618/equilibrium.v4i1.483.

[3] S. Harnani, "Efektifitas Pembelajaran daring di masa pandemi covid-19." BDK Jakarta Kementrian Agama RI, 2020, [Online]. Available: https://bdkjakarta.kemenag.go.id/berita/efektivita s-pembelajaran-daring-di-masa-pandemi-covid-19 .

[4] A. Latifah et al., "Perancangan Sistem Informasi Kohort Ibu Hamil Menggunakan Microsoft Visual Studio 2010 Jurnal Sistem Informasi dan Manajemen," vol. 9, no. 2, 2021.

[5] M. D. H. Y. D. dan S. M. D. Pratita, "Bahan Ajar Sistem Informasi Manajemen,” Manaj. Sist. Inf., 2015.

[6] I. N. R. Hendrawan, "Dokumen Deskripsi Perancangan Perangkat Lunak Sistem Pengarsipan Surat Masuk dan Surat Keluar,' J. Sist. Dan Inform., vol. 10, pp. 110-118, 2015.

[7] S. Thya Safitri., "contoh DPPL," 2017.

[8] IEEE 1016, IEEE Standard for Information Technology - Systems Design - Software Design Descriptions. New York, 2009.

[9] M. Kania Sabaria, "Sample,” 2011. 